\title{
1 Desiring Foods: Cultivating Non-Attachment to Nourishment in Buddhist Sri Lanka
}

\section{Abstract}

3 Food and desire are intimately entangled whereby food becomes a core tool to manage desire

4 in fashioning oneself as a morally virtuous person. This paper looks at the ways in which

5 Buddhist texts conceptualize human interactions with food and formulate prescriptions on

6 how to handle food as a means of developing an attitude of non-attachment that aids in

7 achieving nirvana - the extinguishing of desire to get released from the cycle of death and

8 rebirth. The particular texts - the Agañña Sutta, the Āhāra Patikūlasaññā, and the Vinaya

9 Pitaka - discussed here exhibit an attitude of deep ambiguity towards food in its capacity to incite desire. On the one hand nutrition is required to maintain life, but on the other, food can potentially be the cause of a degenerate state of mankind and a source of moral degradation. Hence, the Buddhist development of a dispassionate attitude towards food seeks to enable both nourishment and the pursuit of the extinction of the flame of desire in nirvana. Even though the texts formulate practical prescriptions for monks on how to relate to food to aid them in their pursuit, they also serve as moral standards for lay Sinhalese Buddhists who seek to model their everyday behaviour accordingly. 


\section{Introduction}

Food and desire are intimately entangled. Desire is expressed in multifarious ways through human interactions with food, ranging from gluttonous indulgence in seductive sweets to selfcontrol in the religious practice of fasting. Anthropologists have described the diverse shapes that this entanglement of food and desire can acquire across different cultural settings, such as in Florence (Counihan 1999), post-socialist China (Farquhar 2002), and Papua New Guinea (Kahn 1986), illustrating its general salience in human life. Moreover, the relation of food and desire is of a mutual nature. Jean Baudrillard (quoted in Belk, Ger \& Askegaard 2003) writes: "everything is reversed if we turn to thinking about the object. Here it is no longer the subject who desires but the object that seduces." The title Desiring Foods precisely denotes both the person desiring the food and the food desiring the person in its seductive capacity. This mutuality of desire invests food with a powerful ambiguity, since desire can be so overwhelming that it leads to loss of self-control involving dangerous social consequences and as such it is met with ambiguous feelings and mixed responses (Belk, Ger \& Askegaard 2003:337). Indeed, as Sigmund Freud (2010) discusses, desire in the form of love can come into opposition to the interests of an orderly civilization which threatens desire by attempting to restrict it for its survival. In a similar way engagements with food have been subjected to moral prescriptions (e.g. table manners) as a means to keep desire in check and develop a civilized attitude (Elias 2000, Rozin 1999). In this paper, I will explore the ways in which Buddhist philosophy and Sinhalese Buddhists in Sri Lanka deal with desire as they carefully craft their engagement with the desire-inducing capacities of food that render it extremely ambiguous.

I will first discuss two texts that are highly evocative of the Buddhist attitude to food and food-related desires: the Agañña Sutta and the Āhāra Patikūlasaññā. The former text discusses 
the role of food in the degeneration of humankind and is known by lay people whereas the second is more oriented towards monks to help them develop an attitude of non-attachment to food by meditating on its repulsive aspects. Thereafter, I will relate some of the emergent themes in these texts to the rules of the Vinaya Pitaka or monastic code on how monks should practically deal with the powerful agency of food, including the rule of not licking fingers, not eating mouthfuls and so forth. Finally, we will look at the way the monastic prescriptions resonate with ordinary everyday practices as these prescriptions constitute an ideal to strive for among lay Sinhalese Buddhists (75\% of the population) as well.

Before discussing these texts, it is important to elaborate the notion of desire more extensively and in a cross-cultural way to provide a general context and overall basis from where the ambiguity of food stems in terms of its desire-inducing capacities. This should start with explaining some basic tenets in Ayurveda and Theravada Buddhism (that draws extensively on ideas and concept of the former) of how the world and its entities, including human beings, are composed and where desire is located.

\section{Ayurvedic and Theravada Compositions of the World}

Ayurveda is an influential health system in South Asia that emerged between 2000 and 2700 years ago (Rodrigues 2006:41) and that radically influenced Theravada Buddhism. Ayurveda views entities in the world as being uniquely composed of various identical substances, but in differentiated combinations and balances. All entities are made up of the five elements (water, earth, fire, wind, and ether), the three humours (wind, bile, and phlegm), and the qualities of rasa (flavour), guna and dosa (presence of beneficial quality or absence respectively) (Seneviratne 1992: 179-184, Obeyesekere 1977: 155-156). Contrastingly, Buddhism discerns five aggregates: those of materiality (which includes the five Ayurvedic elements), feeling, perception, formations, and consciousness (Buddhaghosa 1976:489). The world, its entities, 
human beings and food are as such all composed of identical elements and aggregates distributed in individuated ways accounting for the differentiation into the different entities with their specific characteristics.

Let us now look at where desire is located in all of this. David Webster (2005:51) notes that desire in the Vedic texts (of which Ayurveda is part) has only partially been referred to and often in the context of ritual and sacrificial contexts. Yet, he states that desire in Vedic tradition is central to all activity and that the differentiation of the world implicates desire in its creation, as "Desire forms part of the fabric of the universe" (Webster 2005:53). As such, in Vedic thought desire is everywhere, permeating and animating life. Contrastingly, in the Ayurvedic views on the mind and consciousness, desire is treated more partially and explicitly in theories of mental health and healing. Here, mental health gets disturbed when the five elements and three humours grow out of balance (and get 'excited' and 'angry') and reach the heart, where the mind and consciousness are located (Obeyesekere 1977). Humoral imbalances occur by way of an unbalanced intake of certain foods, thus psychological states and problems can be treated through an adjustment of the diet (see also Hippocrates and Galen, from whom we derived the humour-based concepts of melancholy, colère, etc). For instance, nutritious sweet food that increases the phlegm humour (as well as the water element, the sweet rasa, and semen) in combination with little exercise can cause an excessive sex drive (Obeyesekere 1977:163-164). Hence, the intake of counterbalancing foods and/or the diminution of the intake of nutritious foods help to ease this desire. Moreover, food in general and nutritious food in particular is the fuel for the gastric fire (could be freely translated as the metabolic process) that 'cooks' food in its digestion. The burning fire creates the feeling of hunger as well as of desire. People with a lot of fire are deemed intemperate (badeginni karea: gastric fire person) as well as full of emotional heat. 
Fire in its numerous formations occupies a central place in South Asian worldviews and I have elaborated this more extensively elsewhere (Van Daele 2013). Excessive desire can either be fuelled or tempered by consuming certain cooling or heating foods (in terms of their sensorial effects in the body and not in terms of actual temperature) that impact the humours that then can exert their effects when they reach the heart. So, in Ayurveda we see a symptomatic, curative, and practical approach to wellbeing and desire. Simultaneously the Ayurvedic approach problematizes a clear-cut distinction between the physical and the mental realms. It follows from this introductory description that food and human beings share similar components (elements) and that food clearly affects the human person (by way of humours) as a whole, including the consciousness with which desire is often associated.

Theravada Buddhism deals with desire in more comprehensive, systematic, and existential terms, even though we will see later that it has also developed very practical guidelines to handle it carefully by prescriptions on how to relate to food. David Webster (2005:158) states that in Theravada Buddhism desire arises within the complex of the five aggregates or khandhas - materiality, feeling, perception, formations, and consciousness. The processes that establish the arising of desire and life are not a matter of a single cause and result, but instead entail the complex interplay of conditions that allow the emergence of various effects. The Buddhist teaching on the twelve-fold Dependent Origination or paticca-samuppāda should thus not be read as a mere chain of singular causalities but rather as a multiple interaction of the following elements: "ignorance - formations - consciousness - mind-and-body - six sense-bases - contact - feeling - craving (tanha) - grasping - becoming - birth - ageing, and death, suffering" (Webster 2005:148-149). Link number eight, tanha, points at the appearance of desire out of the former plurality of conditions, while desire simultaneously becomes an enabling condition (among others) for both suffering and creation of life. Because of its 
arising and conditioning, desire almost acquires a metaphysical quality or cosomogenic (cosmos-making) principle in its generativity of life while being operative within the five aggregates. Yet, David Webster (2005:137) opposes the foregrounding of desire in the form of craving or greed (tanha) as the sole creative principle. Instead, desire arises as the result of a co-production of different factors, while it is indeed also pervasive and productive. In short, desire is part of the interactions that it creates and from which it arises and actualizes.

The ambiguity around the status of desire derives from the Vedas, the ancient Hindu texts that have influenced Buddhist doctrine, which state that desire is a creative power that permeates the universe (Webster 2005:53) and so is distributed throughout the various entities of the world, albeit in different degrees. In this light, desire is inherent in both food and human beings who as such can desire each other. Even more, we will see that in the Buddhist story of The Fall (the Agañña Sutta), food is ascribed such a powerful agency and therefore nearly a cosmogenic (creating and shaping the cosmos) power by way of its intrinsic relation to desire.

If viewed in the sense of tanha, desire would only have the negative qualification in Buddhism as metaphysical cause of existence, life, and suffering. However, such a view is one-sided, as Buddhism has a much more varied approach to desire. David Webster (2005:98140) discusses 24 of the manifold desire-related terms that unfold throughout the Buddhist Canon. Some forms of desire are viewed positively, particularly those that are required in reaching nirvana (calm forms of desire, such as compassion and effort). Hence, given the ambiguous nature of desire as being both degenerative (in terms of attachment) as well as creative (in the pursuit of non-attachment) in the Buddhist view, we need to further clarify the status of desire by comparing it to the ways in which it has been viewed in Western scholarship. 
The 24 multiple desires with which Buddhism engages seem to integrate the two main divergent approaches to desire, which Webster (2005:188) discerns among certain scholars in the Western philosophical tradition. On the one hand, there are authors, such as Sartre (Webster 2005:43-44) and Lacan (n.d., Bailly 2009, Goodchild 1996:88-89) who define desire in terms of lack where it is seen as the consciousness of absence, and in which this lack can be traced to the Judeo-Christian notion of the Fall (Sahlins 1996, Loy 1998). On the other hand, scholars such as Deleuze and Guattari $(2009,2011)$ regard desire more as creative and powerful, viewing it as a force that generates relationships and interactions of entities through their mutual transformations, syntheses, and actualizations, and that thus drives productive processes, (Goodchild 1996:4) akin to the Vedic view on desire as a creative force. In Buddhism, both strands of thought seem to be integrated as desire plays a pivotal role in the dependent origination of life (pointing at desire's creative power and sometimes positive role in achieving nirvana) as well as causing the suffering state of humanity in and after the Buddhist Fall (the degenerative and destructive force of desire). As we will see, food plays a pivotal role in inciting desires and clinging throughout the Buddhist texts that we will soon discuss. As such, food must be handled carefully in everyday practice, both by monks in observation of the monastic code, as well as by lay Buddhist followers.

Now that we have scanned this context of Ayurvedic and Theravada Buddhist thought, we are better equipped to grasp the more concrete expressions of the complex entanglement of food and desire. The empirical material that I utilize for the specific analysis has been gathered through library research of translated Buddhist texts, analysing textual references to food and desire, interpreting these in conversations with Buddhist scholars, as well as through interviews, participant observation, and anthropological fieldwork among both urban and rural Sinhalese during three years between 2004-2015. Turning to the Buddhist texts, I will 
first discuss the Agañña Sutta and the Āhāra Patikūlasaññā, which are revelatory of a deep ambiguity towards food and human existence in Buddhist doctrine. Thereafter, I will relate some of the emergent themes from the previous texts with the more practical rules on how monks should deal with the powerful agency of food as stipulated in the monastic code of the Vinaya Pitaka. Finally, I will illustrate that the monastic prescriptions also serve as a moral standard for lay practices.

\section{Agañña Sutta}

The Agañña Sutta or "The Discourse on What is Primary" as translated by Steven Collins (1993:341-348) evokes a Buddhist notion of the Fall into Humanity as related to food and desire. It starts as follows. At the time the world came into being, certain beings entered it. They were made of mind, produced their own light, and moved through the air. At that time, there was only darkness making it impossible to discern any differentiation and individuation into moon, sun, light, man or woman. There was only primordial water, but at some point, an earth essence started covering the water like "the spreading out (of skin) on the top of boiled milk-rice as it cools down. It had colour, smell and taste." (Collins 1993:342) A certain being tasted this sweet essence, became pleased and this experience incited the desire and lust for more (evoking the orientation towards 'sweetness' in life that implies desire). By eating ever more of this earth-essence, these beings' appearance differentiated while they lost some of their capacities. Here we can already see the formative power of food expressed in the text alongside its seductive force initiating the first steps of the Fall into differentiation. The productive force of food and desire is thus viewed as highly ambivalent. Moreover, desire produces clinging, as we have seen in the formula of dependent origination, and the Agañna Sutta continues by saying that due to the pride these beings took in their individuation and differentiation, the earth-essence disappeared, and a fragrant earth emerged with colour, smell 
and taste. The beings started to eat this earth as their food. Their looks became more visible and they increasingly turned arrogant (mobilized by greed), which led to the disappearance of the fragrant earth. Later in the story, rice emerges as the first food as we know it. Reminiscent of the situation in the Garden of Eden prior to the Fall, the beings didn't have to toil their food. Rice grew without cultivation and without husks. No processing was required to eat this sweet-smelling substance. Then, by its consumption: "The female parts appeared in a woman, and the male parts in a man. The woman looked at the man with intensive, excessive longing, as did the man at the woman. As they were looking at each other with intense longing passion arose in them, and burning came upon their bodies; because of this burning, they had sex." (Collins 1993:343-344) So, here we see food as constitutive of differentiated humankind as

well as desire in terms of fire (animating life and fed by food). The craving for food is repeated later in the Agañña Sutta when it describes how the 'immoral' beings increasingly became greedy in collecting the rice and storing it. As a consequence, husk covered the grain and rice had to be harvested, and so these beings started lamenting their state of existence as degenerated human beings. Later on, the story narrates that as people grew ever greedy, they started accumulating possessions in a selfish manner, and in order to quell these unleashed desires, socio-political structures emerged. Hence, desire and food entangle and become productive of sexuality, lust, and lack, as well as the societal arrangements to which both are immanent.

By way of attractive food and their own desire, beings were thus drawn and seduced into existence as human beings and the undesirable cycle of death and rebirth, indicating the text's ambivalent attitude toward food. The theme of degenerative becoming resonates with the Judeo-Christian version of the Fall, in which 'hunger and toil' arose in order to obtain ones' food and to endure the hardships associated with it-weeds, pests and animal-competitors 
(Sahlins 1996:328). In both Buddhist and Judeo-Christian versions, the Fall is induced by an inappropriate burning desire for food (whether metaphorical or not), causing the loss of abilities necessary in obtaining it without suffering and lack. This excessive desire links up with sex, passion, regeneration, arrogance, and impurity. Thus, on the one hand, food is related to the emergence of the world, differentiated life, and productive desire, and on the other hand, food and desire are linked to decay, loss of capacities, and a fundamental sense of lack. In this story we see both Western philosophical approaches (mostly negative as lack and sometimes positive as creative force) combined in a concern with the ambiguous creative and degenerative capacity of food. Finally, from this story it is difficult to discern one single causal factor of the Fall, as the becoming of the world, food, desire, and human beings gradually co-evolve, while being influenced by a previous phase of evolution, differentiation, and degeneration (slightly differentiated beings, fragrant earth, etc).

The ambivalence to food in Buddhism is made more explicit by the text that we discuss next.

\section{Āhāra Patikūlasañ̃̃ā}

This text, which is translated by Pe Maung Tin (1975) from Buddhaghosa's commentaries, shows a more negative view of food as it is translated as "The Development of the Perception of Revulsion from Food”. Buddhaghosa was an important Buddhist scholar and commentator who lived in the fifth century and who wrote commentaries that have profoundly shaped the understanding of Theravada Buddhism. The development of a distinctly negative view on food in this particular text serves the purpose of aiding emotional detachment from food, but not to spur total abstinence. Webster (2005:200) notes that Buddhism is not annihilistic and its middle path avoids extreme deprivation. In such a moderate view, food remains functional to maintain personhood. Conversely, gluttony, indulgence, and sensuous enjoyment of food are not perceived as a necessity, but instead as detrimental because of the arising of desire, 
clinging, becoming, rebirth, and suffering. Hence, the requirement to develop a non-attached attitude towards the dangerously attractive and seductive food emerges.

It is in this light that the summary of the Āhāra Patikūlasaññā (Buddhaghosa 1975: 395-402) should be read. It starts off with an endorsement of the previous statement: "in material food there is the danger of desire (for taste); in contact there is the danger of approach (or attraction to the object); in purpose [I would modify 'purpose' along with Kate Crossby (personal communication) into 'will'] the danger of coming to be; in consciousness the danger of reconception [or rebirth]." (Buddhaghosa 1975:395). Recall that this refers to the twelve-fold Dependent Origination as discussed earlier. Because of this danger of food and desire, the text views it as favourable for monks to develop a revulsion to food by meditating on its abominableness, which manifest itself in ten ways: “(1) From the necessity of having to go for it; (2) of seeking for it; (3) of eating it; (4) because of ingredients; (5) of the receptacle; (6) of its undigested state; (7) of its digested state; (8) of its fruit; (9) of its oozing; (10) of its being smeared" (Buddhaghosa 1975:396). In what follows, I summarize the explanation of each point, foregrounding the most striking elements for our purposes.

1) Because of the necessity of food, the monk has to disrupt his duties to go through the filth on the road to the village, where he has to go for the sake of food. "He arrives near the village gate where he must behold corpses of elephants, of horses, of cattle, of buffaloes, of men, of snakes and dogs...he must also suffer their smell to strike his nose" (Buddhaghosa 1975:397) The section concludes in a formula repeated throughout the text, but mentioned only once here: "thus he should consider its abominableness [of food] from the necessity of having to go for it."

2) In the necessity to search for food, the monk has to suffer filth again as well as harsh speech from the villagers. "Reaching every door he must behold and step into dirty 
pools and pools of mud mixed with the washings of fish, of meat, of rice, with saliva, mucus, dog's dung, pig's dung, and so on, and full of worms and black flies." (Buddhaghosa 1975:397-398)

So, in these first two considerations we see that the attitude of revulsion is cultivated towards the arrangements that emerge around food in order to procure it, rather than food itself, like in the next section, of which I quote a larger part.

3) The villager who sees the food-begging monk is presumed to invite him in so long as

4) The food eaten furthermore becomes loathsome because of the ingredients of bile, phlegm, pus, and blood that are added to the food in digestion. 
5) The food that is smeared with these four ingredients then enters the receptacle or stomach, adding to food's revoltingness, as the stomach "resembles an excrement-pit unwashed for ten years.” (Buddhaghosa 1975:399)

6) Food in an undigested state also finds itself in a loathsome state as it finds itself in the stomach where it is "excessively foul-smelling, of pitch darkness, a passage for the

The purpose of the text, as mentioned earlier is to allow the food to be eaten without inciting 
excited, passionate, and gratifying desire which leads to clinging and becoming. It thus exhibits a strong concern with the seductive potential of food, and proposes a way to overcome this danger by divesting food from its attractive qualities and replacing those with the flip-side of food's ambiguity; its disgusting properties throughout its transformation in the digestive tract. Considering those properties helps to reduce the sense-pleasures with which food is embroiled.

Understanding the repulsiveness of food as a means to subdue its powerful incitement of desire, passion, and craving, helps us locate the purpose of the specific rules of eating as laid out in the Buddhist monastic code, the Vinaya Pitaka.

\section{Vinaya Pitaka Rules on Eating}

The Vinaya Pitaka is a collection of books containing rules and sanctions that aim at shaping the monks' and nuns' behaviour and thereby their self-fashioning as beings nearing nirvana. This monastic code includes prescriptions on receiving alms, sharing food, and eating (how and when), since monks have to exercise restraint to avoid being struck by the powerful capacity of food to incite desire. In its moderation, Buddhism does have a functional approach to food where it is accepted as a necessity for maintaining the body and mental health, but not as something to enjoy. In this regard, the Mahāvagga section of the code makes exceptions to its rules when foods are used as medicine for ill monks (Horner 1962:270).

Additionally, the collection of rules attempts to render the interactions between lay-people and monks pleasant. One example given in the Cūlavagga requires that monks not eat garlic, as teaching the Buddhist Dhamma (collection of teachings) with a bad smell would be a nuisance to the audience (Horner 1952:195). The importance of developing pleasant relations 
with lay people derives from the facts that monks are considered teachers of good conduct who depend on the generosity and goodwill of lay people to give them food.

Most practical rules regarding the dealings with food are expounded in the Suttavibhanga and more specifically in the section of training (Horner 1942:126-140) and I will concisely quote from these rules in what follows. The structure of the rules generally is as follows. It first gives an example of behaviour that led to the rule, then the rule itself, and finally the explanation and qualification of the severity of breaching the rule. Generally, I list the rule in single brackets, but I quote additional information if the rule itself is unclear when taken out of context.

1) 'Attentively will I accept almsfood'... Whoever out of disrespect accepts almsfood inattentively, as though desirous of throwing it away, there is an offence of wrong-doing.

2) ... monks accepted almsfood looking about here and there; they did not know that they were piled up and overflowing... 'Thinking of the bowl will I accept almsfood'.

3) 'I will accept almsfood with equal curry'. (curry to be in measure one fourth of the rice)

4) ... monks accepted heaped-up almsfood. 'I will accept almsfood at an even level'.

5) 'Attentively will I eat almsfood.'

The list of rules with regard to almsfood contains 5 more related rules that I will not list here for reasons of conciseness. The rule discussed next is a rule to facilitate the smooth interactions with lay people.

11) ... monks having asked for curry and conjey for themselves, ate it. People looked down upon ... Who does not like well-cooked things? Who does not like sweet things? [Again we 
see sweetness as a basic and almost universal orientation to food and life] 'I will not eat curry or conjey, having asked for it for myself'.

12) 'Not captious-mindedly will I look at others' bowls'. [Reminiscent of the concern with the evil eye in South Asia and Sri Lanka where it can badly affect the food as well as its consumer. The evil eye often emerges from a desire that turns into jealousy. Many people put up distracting decorations to protect their food, young children, cattle, fields, and houses against the evil eye from people passing through.]

13) 'I will not make up too large a mouthful.'

14) 'I will make up the pieces (of food) into a round.'

15) 'I will not open the door of the face when the mouthful is not brought close.'

357

16) 'I will not put the whole hand into the mouth while eating.'

17) 'I will not talk with a mouthful in the mouth.'

359

18) 'I will not eat tossing up balls (of food).'

19) 'I will not eat breaking up the mouthfuls.'

20) 'I will not eat stuffing the cheeks.'

21) 'I will not eat shaking the hands about [getting rid of the crumbs].'

22) 'I will not eat scattering lumps of boiled rice.'

23) 'I will not eat putting out the tongue.'

24) 'I will not eat smacking the lips.' 
26) 'I will not eat licking the fingers.'

27) 'I will not eat licking the bowl.'

28) 'I will not accept a drinking cup, my hands (soiled) with food.'

29) 'I will not throw out amidst the houses rinsings of the bowl with lumps of boiled rice.'

We can see in our selection (as there are many more rules throughout the entire Vinaya Pitaka) the concerns with a restraint from gluttony, excessive appetite, and indulgence regarding relations with food. Indeed, through the act of eating, it becomes possible to refashion oneself as a morally virtuous person, something that became clear to me when learning to eat decently with my hands and by remarks made during some interviews. Let us now turn to the lay people and everyday eating as an illustration of the resonance with the textual prescriptions.

\section{Everyday Food Life}

Moral codes that are shared often remain implicit until they are breached and when they get explicitly renegotiated. My personal initiation into the Sinhalese moral universe of eating at the start of my fieldwork was one such case. During my first meals among several hosts in Sri Lanka, I was a bit clumsy in eating rice and curry with my right hand. Even though, I had observed the practice and I had been explained how to eat, it took a while before I became skilled. Moreover, through my observation, I could already understand some of the aforementioned boundaries in practice. Unfortunately, during the learning process I did not recognize all the implicit rules which I had occasionally breached. At those times it was made clear what was not acceptable, and in this way my hosts made explicit the moral codes of eating they seek to adhere to. On one occasion I did not know what to do with the sticky leftovers on my fingers, so I discreetly licked them as modestly as possible (against the rule 
26 of the Vinaya Pitaka). At once my host-brother very clearly indicated that this should not be done. Neither could I shake my hand to remove the remainder of the rice (against the rule 21 of the Vinaya Pitaka). Even more out of question, was to use my left hand to remove the leftovers on my right hand, as the left hand is used to wipe the bum and the boundary and distance between the stool and food has to be strictly maintained (Appadurai 2004:80). The only thing to do was to tolerate the drying mess on my fingers until I could wash my hands. These are only a few examples of how lay people live by the rules set out in the Vinaya Pitaka in their daily practice. They may not have read these texts directed to monks, but I suggest these standards have influenced the wider morality of society through the intense engagements with monks at rituals and at the Sunday schools in temples. Hence, the rules of everyday eating coincide remarkably well with the Vinaya prescriptions, which is why they are quoted at length.

The everyday implicit rules of how to eat decently, that turn explicit when transgressed, likewise deal with the concern of avoiding excessive desire and its display. When asking an interviewee how he would perceive me if I ate with the food touching the palm of my hand (excessive amount), licked my fingers, smacked, and so on, he answered that I would be like a hungry ghost (preta wagē), thus viewing me with disgust, linking hunger to greed by way of gut feelings (Roberson 2001:14). So, by way of eating the human person can fashion himself as such and distinguish from certain 'morally lower' people or non-human beings. Pretas are hungry ghosts defined by their excessive and insatiable greed. These beings are the antipole of the aspiration for liberation among Buddhists since they are the epitome of desire gone awry. Many people fear becoming such ghosts after their death. Indulging in the sensepleasures associated with food resembles the behaviour of pretas. Even more, such behaviour could spark and feed the desire to such an extent that one cannot let go and clings to the food 
(and the home where the deceased person used to eat his/her food) at the moment of death and thus actually becomes a preta. As one can never be sure that a deceased person (friend, relative) will turn into a preta, people cook their favourite food at the place where the body has rested a few days. The consciousness of the deceased gets anchored to this food and the relatives facilitate its departure and detachment by placing the food outside the homestead. In this way they could avoid the deceased sticking to the home as a preta and rather help them pursue the path to nirvana in the afterlife. Given these and other widespread food-related funerary practices, and the remarks made by interviewees, people share with the monks a concern about the powerful seductiveness of food as well as its potential to transform people into morally higher or lesser beings, both in this life and even in the afterlife. Thus the powerfully seductive agency and transformative capabilities of food, as discussed in relation to the Buddhist texts, is also dealt with at a very practical and everyday level by lay people.

\section{Conclusion}

From our discussion, we can see that food and desire are intimately enmeshed in the Singhalese Buddhist discourses and practical engagements with food in general. As such, food turns into a powerful means to refashion oneself as a virtuous person on the path towards nirvana and the release from attachment by desire.

From the texts and illustrative practices, it is clear that food is highly ambivalent, both regenerating and degenerating life. Yet, where is this deep ambiguity coming from? I suggest that part of the answer is given in the wider introduction on both Ayurvedic and Buddhist thought. Given that human beings, the world, and the other entities that populate it are cocomposed of similar elements and forces, albeit distributed in different ways, renders these 
entities radically interpenetrating and mutually permeable (Osella \& Osella 2002:470-471). This entails that entities and human beings are regarded as unstable formations that are thoroughly altered in their being throughout interaction. In this regard we can understand that eating is a highly charged activity surrounded by multiple precautions and taboos (e.g. avoidance of sharing food across different castes in order to avoid moral pollution). Desire is a powerful creative and destructive force that in its enmeshment with food further increases the latter's ambiguity and both require careful negotiation in monastic and lay life. To get released from the cycle of death and rebirth in order to reach nirvana, the development of an attitude of non-attachment to food plays a crucial role, since dealing with food is actually a way of dealing with desire. The texts discussed ponder these themes and seek to aid people (especially monks) in this pursuit of the extinguishing of desire in nirvana. As such, they aid in the development of a civilized and moral attitude in society that keeps basic human forces in check.

\section{Acknowledgements}

I wish to thank Kate Crossby for informing me of valuable translations of the Buddhist texts used here and for discussing them with me. I am also grateful to Vito Laterza for reviewing an earlier version of this text. Yet, both bear no responsibility whatsoever on the claims made here. Finally I wish to express my gratitude to the Pali Text Society for generously granting me the permission to quote extensively from their published translations. Finally, I wish to thank the European Research Council under the European Union's Seventh Framework Programme (FP7/2007-2013) / for the ERC Grant Agreement nr 295843. 


\section{References}

461

462 463

464

465

466

467

468

469

470

471

472

473

474

475

476

477

478

479

480

481

482

483

484

485

486

487

488

489

490

491

Appadurai, A. (2004). The Capacity to Aspire: Culture and the Terms of Recognition. In V.

Rao, \& M. Walton (Eds.), Culture and Public Action (pp. 59-84). Delhi: Permanent Black.

Bailly, L. (2009). Lacan: A beginner's guide. Oxford: Oneworld Publications.

Belk, R.W., Ger G., \& Askegaard S. (2003). The Fire of Desire: A Multisited Inquiry into Consumer Passion. Journal of Consumer Research 30(3), 326-351.

Buddhaghosa, B. (1975[n.d.]). The Path of Purity [Visuddhimagga]. London: The Pali Text Society.

Buddhaghosa, B. (1976[n.d.]). The Path of Purification [Visuddhimagga]. Boulder: Shambhala.

Collins, S. (1993). The Discourse on What is Primary (Agañña-Sutta): An Annotated Translation. Journal of Indian Philosophy 21(4), 301-393.

Counihan, C. (1999). The Anthropology of Food and Body: Gender, Meaning, and Power. New York: Routledge.

Deleuze, G., \& Guattari, F. (2011[1972]). Anti-Oedipus: Capitalism and Schizophrenia. London: Continuum.

Deleuze, G., \& Guattari, F. (2009[1980]). A Thousand Plateaus: Capitalism and Schizophrenia. Minneapolis: University of Minnesota Press.

Elias, N. (2000). The Civilizing Process: Sociogenetic and Psychogenetic Investigations. Malden: Blackwell Publishing.

Farquhar, J. (2002). Appetites: Food and Sex in Post-Socialist China. Durham: Duke University Press. 
492

493

494

495

496

497

498

499

500

501

502

503

504

505

506

507

508

509

510

511

512

513

514

515

516

517

518

519

520

521

522

523

524

Freud, S. (2010). Civilization and its Discontents. New York: W.W. Norton \& Company.

Goodchild, P. (1996). Deleuze \& Guattari: An Introduction to the Politics of Desire. London: Sage Publications.

Horner, I. B (trans). (1942). The Book of the Discipline (Vinaya-Pitaka), vol. 3: Suttavibhanga. London: Oxford University Press.

Horner, I. B (trans). (1952). The Book of the Discipline (Vinaya-Pitaka), vol. 5: Cullavagga. London: Luzac \& Company.

Horner, I. B (trans). (1962). The Book of the Discipline (Vinaya-Pitaka), vol. 4: Mahāvagga.

London: Luzac \& Company.

Kahn, M. (1986). Always Hungry, Never Greedy: Food and the Expression of Gender in a Melanesian Society. Cambridge: Cambridge University Press.

Lacan, J. (N.d.). The Seminar of Jacques Lacan: Desire and its Interpretation, 1958-1959, book 6. London: Karnac Books.

Loy, D. R. (1999) The Spiritual Roots of Modernity: Buddhist Reflections on the Idolatry of the Nation-State, Corporate Capitalism and Mechanistic Science. In S. Sivaraksa, P. Udomittipong, \& C. Walker (Eds.), Socially Engaged Buddhism for the New Millennium: Essays in Honor of The Ven. Phra Dhammapitaka (Bhikkhu P.A. Payutto) On his 60 Birthday Anniversary (pp. 86-113). Bangkok: Sathirakoses-Nagapradipa Foundation and The Foundation for Children.

Obeyesekere, G. (1977). The Theory and Practice of Psychological Medicine in the Ayurvedic Tradition. Culture, Medicine and Psychiatry, 1:155-181.

Osella, F., \& Osella, C. (2002). Quelques points de vue sur l'inné et l'acquis au Kerala, Inde du Sud. In V. Bouillier, \& G. Tarabout (Eds.), Images du corps dans le monde hindou (pp. 467-495). Paris: CNRS editions. 
525 Rodrigues, H. P. (2006). Introducing Hinduism. New York: Routledge.

526

527 Robertson, A. F. (2001). Greed: Gut feelings, growth, and history. Cambridge: Polity Press.

528

529 Rozin, P. (1999). Food Is Fundamental, Fun, Frightening, and Far-Reaching. Social Research 530 66(1): 9-30.

531

532 Sahlins, M. D. (1996). The Sadness of Sweetness: The Native Anthropology of Western

533 Cosmology [and Comments and Reply]. Current Anthropology. 37(3):395-428.

534

535 Seneviratne, H. L. (1992). Food Essence and the Essence of Experience. In R. S. Khare (Ed.),

536 The Eternal Food: Gastronomic Ideas and Experiences of Hindus and Buddhists (pp. 179-

537 200). Albany: State University of New York Press.

538

539 Van Daele, W. (2013). Igniting Food Assemblages in Sri Lanka: Ritual Cooking to

540 Regenerate the World and Interrelations. Contributions to Indian Sociology, 47(1):33-60.

541

542 Webster, D. (2005). The Philosophy of Desire in the Buddhist Pali Canon. London:

543 Routledge. 